\title{
On Dramatic Characteristics of SUN Yu-tang's Poetry
}

\author{
XU Jin-qiong, JIANG Deng-ke \\ Modern Chinese Poetry Research Institute, Southwest University, Chongqing, China
}

\begin{abstract}
The dramatization of poetry has been the major development tendency of western poetry since 1830. Chinese modern poets are committed to the dramatization of new poetry with reference to western poetry. At present, many researchers in Mainland China regard WEN Yi-duo, XU Zhi-mo, and BIAN Zhi-lin as pioneers for advocating and implementing the dramatization theory of Chinese poetry. Thereafter, Jiuye poets believe the dramatization of new poetry as the voluntary pursuit of poetic art, which improves the modernization level of new poetry to a new height. The author discovered that poetic creation of Mr. SUN Yu-tang in 1920s and 1930s reflected the dramatic tendency. From dramatic voice, dramatic action, dramatic scene, and dramatic structure, the function and significance of poetic creation of SUN Yu-tang for avoiding abuses in the poetic circles at that time and enlightening the creation of contemporary new poetry are discussed in this paper.
\end{abstract}

Keywords: Sun Yu-tang, poetry, dramatization

\section{Introduction}

The pursuit of dramatization is an important characteristic of modernism poetry.

The dramatization is originated from western countries, especially the drama theory in western countries. From the era of Aristotle, the drama has been the crown of western literature which is the same as that the lyric poetry is the standardized form of Chinese literature. The drama theory has been the core of theories of western literature for a long time and has significant influence on other categories of literary theories in western countries, including modernism poetry concept and theory. (JIANG, 2003, p. 17)

The dramatization of poetry converts the subjective lyrical expression of poetry to objective and calm expression, which has been the main development tendency of western poetry since 1830. "No matter 'implication' of Paul-Marie Veriaine, 'objective correlative' of Charles Baudelaire, 'impersonalization' of Eliot, 'perspective' of Rainer Maria Rilke or 'tact' of Auden or other poetics all reflected this tendency” (XU, 2005, p. 207). In China, the concept "dramatization of poetry" enlightened by western poetry is the main route and expression mode of modernization of new poetry. At present, many researchers in Mainland China regard WEN Yi-duo, XU Zhi-mo, and BIAN Zhi-lin as pioneers for advocating and implementing the dramatization theory of Chinese new poetry when tracing back to the origin of dramatization of Chinese poetry. Thereafter, Jiuye poets believe the dramatization of new poetry as the voluntary pursuit of poetic art, which improves the modernization level of new poetry to a new height. For example, WANG Chang-zhong, in a paper discussing dramatic 
characteristics of Chinese new poetry in 1990s, mentioned representative poets of dramatization of Chinese new poetry, "in China, the dramatization has been continuously advocated and implemented by new poets pursuing modernization of new poetry, like WEN Yi-duo, BIAN Zhi-lin, YUAN Ke-jia, etc.” (WANG, 2009, p. 50), so only WEN, BIAN, and YUAN were mentioned; SUN Xiang-yang summarized the development history of dramatization of Chinese new poetry in his master graduation thesis,

WEN Yi-duo introduced and implemented the dramatization of poetry in China at the earliest... BIAN Zhi-lin inherited the dramatization theory of WEN Yi-duo and applied this theory to an "intermediary" character in the poetic circles in 1940s... YUAN Ke-jia is a theorist developing the dramatization theory of poetry to perfection and mature. (SUN, 2009, pp. 5-6)

All above opinions are to the point. However, during reading, the author discovered that the poetic creation of Mr. SUN Yu-tang who was in the same era with WEN, XU, and BIAN and had very deep friendship with WEN Yi-duo in 1920s and 1930s also reflected the dramatic tendency. The author will make a detailed discussion from dramatic voice, dramatic action, dramatic scene, and dramatic structure.

\section{Dramatic Voice}

The so-called dramatic voice refers to that, to avoid direct presentation of the poet's opinion "I" or direct expression of poetic minds in the poem, the poet will insert dramatic dialogue, monologue, or voiceover in the poem, narrate the plot, depict personal character, reveal theme, or express thoughts and feelings of the poet in a zigzag and indirect manner by fictional voice of characters. Virtual role in the poem is not always the objective observation object of the poet but the zigzag reflection of the second ego even the third ego of the poet. Different voices form the polyphony to comprehensively reveal inner contradiction and richness or profoundness of life philosophy.

There are three expression forms. One is dialogue form, i.e., the third person usually replaces the first person or several persons interactively form the complex and changeable voice combination. There are many dialogues in SUN Yu-tang's poetry. For example, the poem Send depicts the dialogue between a friend who will go far away and me before parting. (First two strophes are omitted here.)

The rain covers the boat and the sea / "I will come back in three to five years!" / Gosh, how many days in three to five years? / It just rained last night, the moss on hillstone has turned green II "I have to go when the lotus is withered"/ But you are sad as the autumn comes too early here / until the lotus seed is mature / the lotus leaf is also old / and the green bristlegrass is growing tall at the edge of eaves II "Will you stay for longer time? You may feel lonelier on the way in the autumn rains". You say nothing / Autumn rains are flowing on the windowpane like tears / the hollow scar of autumn rains is accumulated on the windowpane one by one/revealing the words of autumn rains II "If it's still raining tomorrow / YU Sheng, I will hold an umbrella to send you / Two lightly heavy rusts shake / iron bell before the eaves, and shake / green bristlegrass at the edge of eaves-wind. (SUN, 2013a, pp. 71-72)

The first and second strophes of quoted poem are farewells of YU Sheng to the poet. The poet does not immediately make response but keeps silence, which builds the dignified feeling at the scene. However, the poet makes response by psychological monologue, which implicitly expresses his sorrow and worry for parting with the friend for several years. The poet expresses that "YU Sheng" feels reluctant to leave in a zigzag manner by the image of "YU Sheng" in the eye of the poet — postponing the time of parting for several times with the excuse that "the autumn comes too early here". The third and fourth strophes are corresponding to the first and second 
strophes: I persuade "YU Sheng" to stay for longer time, "YU Sheng" keeps silence, but surrounding sceneries like "tear of autumn rains", "hollow scar of autumn rains", sound of "heavy rust", etc., seemingly respond the poet; therefore, the loath to part from each other is vividly depicted between the lines.

The second and third categories are respectively monologue and voiceover. The dramatic monologue refers to the monologue of others rather than the author in specific dramatic scene and the poet will make no hint or explanation. The monologue character is talking with another virtual "silent listener", forming the echo. The "silent listener" cannot speak from the start to the end, so the reader can only feel the existence, words, and deeds of another person from the words of the monologue character. The dramatic voiceover is that a character is inserted in the poem to speak, which pushes or reminders the drama scenario or purport and is equivalent to the "voiceover". The two voices are used together to jointly reveal the theme of a poem. Selling Wine comprehensively adopts dramatic monologue and voiceover.

A boat full of wine is approaching the ferry station by the barge pole / the salesman is shouting for selling wine on the river in the twilight: / wine, wine! Tasty wine! / One pot, only ten copper coins! II ("You can forget the tiredness of ten years if you buy the wine with ten copper coins (ancient currency of China) / You can forget the hardship in the life after drinking a pot of wine)... Wow, wow, the moon comes out, two legs are almost broken, I only earned about one hundred copper coins in a day / I'm thirsty and really want to drink wine / What a pity, it costs ten copper coins, and it's too expensive! II There is no salt at home, and I have to buy noodles / I still owe a bill to Mr. Yang... / (Wine, wine! Tasty wine! You can forget all your worries with a pot of wine.) II It's hateful that boss Wang asks for a discount, hum / my shoulder is still painful from the morning / fucking gunny bag is heavy as a stone mill; till night / I can buy three cakes with two bad onions II Remaining money can only used to buy rice vermicelli of $500 \mathrm{~g} /$ otherwise, my wife and child (Xiaojiuer) would suffer from hunger / Forget it and endure it, go back to sleep! / The shallow of moon in the river center has laughed its mouth crooked II "Wine, wine! Tasty wine!..." / Dame it! Does it attract the greedy of your grandfather? / (You can forget the tiredness of ten years if you buy the wine with ten copper coins / You can forget the hardship in the life after drinking a jug of wine)... (SUN, 2013b, pp. 211-213)

The yo-heave-ho for selling wine at the ferry station (monologue), voiceover in the bracket and internal monologue of boat waiter are repeated in the poem, which incisively and vividly reveal the psychological process of fierce struggle between desire and rationality of the boat waiter. The monologue at the ferry station is the opening words and penetrating line for the whole poem. The internal monologue of boat waiter represents rational ego, although voiceover in the bracket is voice over but actually represents another emotional ego of the boat waiter, which reflects the most original and true desire of the boat waiter: "You can forget the tiredness of ten years if you buy the wine with ten copper coins. You can forget the hardship in the life after drinking a pot of wine". The boat waiter is full of desire but the cruel reality draws him back to the rational ego: Meager income, heavy family burden, and so hard living conditions, wine is a luxury good unaffordable by the boat waiter. As one falls another rises of the yo-heave-ho for selling wine by the boat waiter, two egos of the boat waiter are falling and rising and struggling. The ferryman gradually goes far; finally, the rational ego of boat waiter overcomes the emotional ego. This poem is full of dramatic effect and implicitly expresses the deep sympathy of the poet to the living conditions of roughscuff.

\section{Dramatic Action}

In essence, the drama is the art of action. It mainly expresses personal character from (internal and external) action. Hegel (1981) once said: "Action can clearly express personal character, thoughts and purposes" (p. 270). 
Main characteristic of dramatic action in the poem is to constitute a conflict, express personal character, and reveal the poetic theme by behavior conflict between personal heart and people and people or people and environment.

Rose reveals the behavior conflict among rose, "I", and fallen flowers by the anthropopathic method.

A rose is vividly dancing / blooming with smile towards spring sunshine / dreaming of Vermillion May / and waiting for gentle south wind / Tell me how crazy bees suck / and how nice butterflies fly / I lower my head and keep silent / I stare at joyful dancing in the wind / I remember that the rose in last year / was complaining sorrow and bitterness in the cold rain: / tell me how withered flowers drop down / and how fallen flowers become mud. (SUN, 2013c, pp. 199-200)

This poem adopts the method of praise before criticizing. The poem firstly depicts several dramatic actions of a rose with elegant and unique appearance: "vividly dance", "bloom with smile", "wait", "tell me", which vividly reflect the hopeful and prosperous expression and psychology. Facing flaunt of rose, I "lower my head and keep silent". My silence and self-aggrandizement of rose form a sharp contrast. Meanwhile, the poet sets the suspense for the reader to track down with doubts. Really, the last four sentences uncover the answer: Two sorrowful actions of fallen flowers such as "complaint of bitterness" and "crying" and action and expression of an exquisite rose constitute strong dramatic conflict, which reveal the tragic fate that the short-lived "beauty" will finally become fallen flowers and mud. This poem depicts a short-lived rose, which reveals the philosophy that human and all things in the world cannot disobey natural laws.

\section{Dramatic Scene}

Dramatic scene refers to the objective activity environment of characters and specific character relation. Action and voice of characters in the drama are all included in the scene. Only in specific dramatic scene, the dramatic action and voice of poetry can realize its significance.

In Sleeping Child, the surrounding gloomy and horrible environment and the sweet and naive dream of sleeping child form a sharp contrast, and the strong contrast deeply expresses the "white terror" of the society at that time and the fear psychology of the poet.

The child is sleeping at night / with innocent smile / although the child is in the real world / his soul is in the dream II He is dreaming of "the beauty of moon" / the bird's wing and the fish tail... / but the black claw of night / covers his limbs. II The autumn wind is crying in the forest / the cold rain is flipping the window / the cold night / is enveloped in sorrowful death atmosphere II With holy simile / he has no fear and regret/he is dreaming of "the beauty of moon" / the bird's wing and the fish tail... (SUN, 2013d, p. 198)

The first six strophes depict a naive and pure child sleeping at night. Although he is "living in the real world", it is a beautiful and pure fairy tale world in the eye of an innocent child. He is dreaming of "the beauty of moon", "the bird's wing", and "the fish tail". This picture is peaceful, warm, and sweet. From the seventh strophe, the emotional key of the poem takes a sudden turn and becomes worse rapidly like the conversion lens angle in the film and the poem depicts scene features: The night stretches "black claw", the autumn wind "is crying", the cold rain is flapping the window, so the night is enveloped in the sorrowful death atmosphere. A series of images build a very eerie atmosphere. In the last strophe, the shot turns to the sleeping child again, which is similar to the first six strophes, it presents the smooth, steady, and beautiful dream scene of the sleeping child. In the strong contrast of repeated replacement of scenes, the reader cannot help feeling the inner fear of the poet. 


\section{Dramatic Structure}

"All elements in the drama are to pursue one purpose and one intention" (WU, 1983, p. 191) which determines the unity between action and theme in the drama. It is to pursue internal consistency among the penetrating line of action of character in the drama, the development line of personal character, and penetrating line of theme so as to constitute double-layer inner structure of dramatic poetry. For example, Firefly:

In the childhood, people like looking up the starry sky / fireflies fly up above the sky, become immortal and never fly back: / each star is a hope II In the old age, people like looking at fireflies above the river / fireflies fly after ones in the river center / when tired, fireflies fall down to the wet tomb grass like a flashing meteorite. (SUN, 2013e, p. 216)

Two different temporal scenarios are used in this poem as replacement and comparison so as to reach a dramatic effect: In the childhood, people like looking up the starry sky, which is full of fairy tale fantasy, and regard that firefly is the immortal in the sky. In the old age, people like looking at fireflies over the river, and regard the fireflies just "fall down to the wet tomb grass after being tired". From the surface structure, the poet expresses different perspectives of people looking at fireflies in the childhood and old age. However, the charm of the poem is mainly from its internal structure: In the childhood, our heart was simple and clean as a piece of white paper; we were full of various dreamy expectations for life and future. As we grow up, we tasted joys and sorrows of life and experienced fickleness of human nature, we turned sophisticated and calm, however, the maturity is full of so many sadness and helplessness of life. Coincidentally, the artistic method and artistic conception of this poem are similar to Lyrics to the Melody Dedicated to Lady Yu by JIANG Jie, Ci poet of the Southern Song Dynasty,

In my youth I listened to the rain in houses where singing pervaded, surrounded by bed curtains that candlelight veiled. In my prime I listened to the rain as I travelled by boat, the river was vast and clouds low, in westerlies trilled wild geese lost on their way. These days I listen to the rain in the hut of a monk, my sideburns have turned sparkling grey. Ever so relentless are the joy of coming together and parting sorrows that follow, here I am taking heed of the rain dribbling on the stairs as a new day breaks. (GUO, 1998, p. 258)

Two poems build the dramatic conflict by comparison of two or several different temporal scenarios. Meanwhile, the internal and external dramatic structure building reveals the changing world outlook and mournful mental state in the old age, which is full of philosophy.

\section{Conclusion}

T. S. Eliot (2010) once said "poetry is not the indulgence of emotion but the separation of emotion; the poetry is not the expression of personality but the separation of personality" (p. 8). The dramatization of poetry is the main realization approach and performance characteristics of modernization of new poetry. The means of expression can more pertinently express more complicated mental consciousness of the modern people, which can reach the objective, indirect, and implied curvilinear style poetic expression effect. YUAN Ke-jia once pointed out abuses in the poetic circles in 1940s:

At present, there are roughly two categories for most poems we read: One is to explain strong will or faith, aiming to effectively influence the will or belief of others; the other one is to express some fantastic emotion of oneself, aiming to moving others in the same time; most poets who express will have not exactly belief, use powerful words at the beginning and husky tone to call for "I want..." or "we don't want..." or "we advocate..." or "we oppose..." Most poets who express passion have clear love and hate object and make bare statement accusing. (YUAN, 1994, p. 67) 
However, "expression of will finally becomes preachy, expression of emotion become sentimental" (YUAN, 1994, pp. 67-68), which is free of poetic art. In fact, the poetic phenomenon was emerged in the initial stage of birth of new poetry. For example, in the initial stage, general reasoning tendency in free vernacular verse, a direct emotional expression of the romantic poetry and revolutionary poets' preaching of will, all of these we affirm their pioneering social and historical significance, but at the same time we should admit its deviation from aesthetic essence of poetry. Mr. SUN Yu-tang did not create theoretic articles discussing or advocating dramatization of poetry for us (like WEN Yi-duo \& BIAN Zhi-lin), the application of dramatization in his poems was not as mature as the application by Jiuye poets in 1940s, but he is one of the new poets adopting the dramatization method, which is valuable and reveals his keen intuition on poetics. Meanwhile, the exploration on dramatic poetic art of SUN Yu-tang has the function and significance for avoiding abuses in the poetic circles at that time and enlightening the creation of contemporary new poetry.

\section{References}

Eliot, T. S. (2010). Literary essays of Eliot. Nanchang: Baihuazhou Literature and Art Publishing House.

GUO, Y. H. (1998). History of ancient Chinese literature (Vol. III). Shanghai: Shanghai Classics Publishing House.

Hege, G. (1981). Aesthetics: Volume I. Beijing: Commercial Press.

JIANG, D. K. (2003). On the pursuit of dramatization of Jiuye poets group. Shenyang: Journal of Shenyang Normal University.

SUN, X. Y. (2009). Analysis of dramatic strategies in Niu Han's poetry. Chongqing: Modern Chinese Poetry Research Institute, Southwest University.

SUN, Y. T. (2013a). Send. In Poetry anthology of SUN Yu-tang. Beijing: Commercial Press.

SUN, Y. T. (2013b). Selling wine. In Poetry anthology of SUN Yu-tang. Beijing: Commercial Press.

SUN, Y. T. (2013c). Rose. In Poetry anthology of SUN Yu-tang. Beijing: Commercial Press.

SUN, Y. T. (2013d). Sleeping child. In Poetry anthology of SUN Yu-tang. Beijing: Commercial Press.

SUN, Y. T. (2013e). Firefly. In Poetry anthology of SUN Yu-tang. Beijing: Commercial Press.

WANG, C. Z. (2009). On dramatic characteristics of Chinese poems in 1990s. Hangzhou: Journal of Tourism College of Zhejiang. WU, L. F. (1983). Selected western papers (Vol. II). Shanghai: Shanghai Translation Publishing House.

XU, T. (2005). The analects of Chinese modernism poetics. Shanghai: Shanghai Cultural Press.

YUAN, K. J. (1994). Footprint of a half century: Selected poems and essays of YUAN Ke-jia. Beijing: People's Literature Publishing House. 